\title{
PENINGKATAN HASIL BELAJAR PESERTA DIDIK DENGAN MENGGUNAKAN MODEL PYTHAGORAS PADA MATA PELAJARAN MATEMATIKA DI KELAS VIII.1 SMP NEGERI 4 BASO
}

\author{
Oleh: Usyeldi \\ usyeldy@yahoo.co.id \\ SMP Negeri 4 Baso
}

\begin{abstract}
Pembelajaran matematika di Sekolah Menengah Pertama Negeri (SMPN) 4 Baso dilaksanakan melalui kegiatan ceramah yang lebih dominan. Masih banyak peserta didik yang belum tuntas belajar matematika. Salah satu upaya yang untuk meningkatkan hasil belajar adalah dengan menggunakan model Pythagoras sebagai media pembelajaran. Tujuan penelitian adalah untuk meningkatkan hasil belajar peserta didik menggunakan model Pythagoras pada materi Teorema Pythagoras di kelas VIII.1 SMPN 4 Baso Kabupaten Agam pada Tahun Pelajaran 2015/2016. Penelitian menggunakan rancangan penelitian tindakan kelas. Subjek penelitian adalah siswa kelas VIII.1 SMP N 4 Baso pada Tahun Pelajaran 2015/2016 sebanyak 20 orang. Pengumpulan data menggunakan tes dan observasi. Tes digunakan untuk mendapatkan hasil belajar peserta didik pada setiap siklus. Observasi digunakan untuk mengetahui proses pembelajaran pada setiap siklus. Data dianalisis dengan statistik deskriptif. Hasil penlitian adalah: Nilai rata-rata hasil belajar peserta didik pada siklus I sebesar 66,5, pada siklus II sebesar 75,5 sehingga terdapat kenaikan nilai rata-rata dari siklus I ke siklus II. Prosentase ketuntasan belajar peserta didik pada siklus I sebesar 60\%, pada siklus II sebesar $95 \%$. Dengan demikian terdapat peningkatan ketuntasan belajar peserta didik dari siklus I ke siklus II. Dengan demikian dapat disimpulkan bahwa pembelajaran matematika dengan menggunakan model Pythagoras dapat meningkatan hasil belajar peserta didik.
\end{abstract}

Keywords: Model Pythagoras, hasil belajar.

\section{PENDAHULUAN}

Kemajuan ilmu pengetahuan dan teknologi sangat mempengaruhi pendidikan saat ini. Berbagai analisis menunjukkan bahwa pendidikan nasional sedang dihadapkan pada berbagai krisis yang perlu mendapat penanganan secepatnya, diantaranya berkaitan dengan masalah relevansi atau kesesuaian di antara pendidikan dengan kebutuhan masyarakat dan pembangunan. Untuk mewujudkan hal tersebut, peran guru sangat dibutuhkan dalam pendidikan. Tanpa peran aktif guru, kebijakan perubahan pendidikan akan sia-sia. Oleh karena itu guru dituntut untuk memiliki kemampuan mendesain pembelajaran, menentukan strategi, memiliki ketrampilan memilih dan menggunakan model pembelajaran yang efektif. Penggunaan metode yang tepat akan menentukan efektivitas dan efisiensi pembelajaran (Winkel, 2005).
Disamping pentingnya peranan guru, perkembangan ilmu pengetahuan dan teknologi memungkinkan semua pihak memperoleh informasi yang melimpah, cepat dan mudah dari berbagai sumber dan tempat di dunia, termasuk di dalamnya ilmu matematika. Dengan demikian siswa perlu memiliki kemampuan memperoleh, memilih dan mengelola informasi untuk bertahan pada keadaan yang selalu berubah, tidak pasti dan kompetitif. Kemampuan ini membutuhkan kemampuan berpikir kritis, sistematis, logis, kreatif serta kemampuan bekerja sama yang efektif dan efisien. Cara berpikir seperti ini dapat dikembangkan melalui belajar matematika, karena matematika memiliki struktur dan keterkaitan yang kuat serta jelas antara konsep satu dengan konsep yang lainya, sehingga memungkinkan kita terampil berfikir rasional. 
Belajar matematika bersifat abstrak, sehingga menuntut guru harus teliti dalam menggunakan metode pembelajaran maupun pendekatan dalam pembelajaran matematika. Secara singkat dikatakan bahwa matematika berkenaan dengan konsep-konsep abstrak yang tersusun secara hirarkis dan penalarannya deduktif. Matematika merupakan mata pelajaran yang dianggap sebagian besar siswa sebagai mata pelajaran yang sulit untuk dipelajari. Hal ini disebabkan karena proses pembelajaran matematika di sekolah masih menggunakan pendekatan konvensional. Banyaknya masalah dalam pembelajaran matematika di sekolah, menjadikan salah satu alasan untuk mereformasi pembelajaran matematika. Masalah umum dalam matematika adalah rendahnya daya saing peserta didik diajang international, rendahnya rata-rata ujian nasional (UN), serta rendahnya minat belajar matematika.

Pembelajaran dengan media maksudnya adalah cara yang digunakan oleh guru dalam menyampaikan materi pelajaran dengan menggunakan alat bantu yang sesuai dengan materi yang diajarkan (Ibrahim, 2012). Salah satu manfaat yang dapat diperoleh dari pembelajaran dengan media adalah memudahkan guru dan peserta didik dalam mempelajari dan memahami materi pelajaran (Arsyad, 2011). Media pembelajaran meliputi fasilitas yang dapat digunakan untuk menyampaikan pesan atau bahan pelajaran kepada peserta didik untuk memperjelas, memperlancar, dan meningkatkan proses dan hasil belajar.

Penggunaan media dalam pembelajaran perlu persiapan yang cukup. Kesalahan yang sering terjadi ialah timbulnya anggapan bahwa dengan media pembelajaran, guru tidak perlu membuat persiapan mengajar lebih dahulu. Justru sebaliknya dalam hal ini guru dituntut untuk melakukan persiapan dengan cermat dengan mempelajari bahan dalam buku sendiri, mempersiapkan bahan, pengayaan dan penjelasan. Media pembelajaran hendaknya tidak sekedar menjadi selingan, hiburan, atau pengisi waktu, tetapi harus disesuaikan dengan tujuan pembelajaran.

Berdasarkan klasifikasinya, media pembelajaran dapat dikelompokkan menjadi lima jenis, yaitu: (1) media grafis, (2) media gambar dan ilustrasi fotografi, (3) media bendanya, (4) media proyeksi, dan (5) media audio (Hamalik, 1992). Mengingat beraneka ragamnya media pembelajaran yang masing-masing mempunyai karakteristik sendiri-sendiri, maka guru harus berusaha memilih dengan cermat agar dapat digunakan secara tepat. Hal ini sesuai dengan yang dikemukakan Ngadino (1986) bahwa hingga kini belum ada suatu rumus yang berlaku mutlak untuk melakukan pemilihan media tertentu, untuk melakukan pengajaran suatu obyek tertentu. Dengan kata lain tidak ada suatu media yang lain untuk mencapai segala macam hasil yng diharapkan dan untuk segala jenis pelajaran. Dari berbagai penelitian di bidang media dan desain sistem intruksional, yang dapat dirumuskan hanyalah pedoman umum atau pedoman pokok untuk melakukan berdasarkan berbagai macam variabel yang terdapat dalam suatu sistem intruksional.

Survei awal menunjukkan bahwa pada proses pembelajaran matematika di kelas VIII.1 tentang Teorema Pythagoras guru menerapkan metode ceramah, media papan tulis. Guru menjelaskan materi peserta didik mendengarkan. Guru mengadakan tanya jawab, sebagian peserta didik belum ada yang bertanya. Pelaksanaan pembelajaran kelompok tidak berjalan maksimal karena kebanyakan siswa menghabiskan waktunya untuk bermain dengan anggota kelompok. Perhatian dan motivasi siswa ketika belajar matematika kurang. Bahkan beberapa siswa lebih senang bermain dibanding belajar. Hal ini dipicu karena metode pembelajaran yang diterapkan kurang menarik. Siswa belum paham dan merasa kesulitan dalam mengerjakan soal, dikarenakan sebagian besar siswa tidak memahami materi melainkan menghafal langkah-langkah penyelesaian soal. Jika diberi soal yang sedikit berbeda dengan contoh soal siswa sering merasa kebingungan. Hasil belajar peserta didik adalah 
nilai tertinggi: 80 , nilai terendah: 50 dan rata-rata nilai: 60. Sebagian besar peserta didik belum tuntas belajar matematika. Kriteria Ketuntasan Minimal (KKM) yang ditetapkan adalah 70 .

Faktor penyebab banyaknya peserta didik yang belum tuntas belajar matematika, antara lain pembelajaran terpusat oleh guru, siswa sebagai pendengar pasif, dan kurangnya variasi dalam proses pembelajaran. Salah satu alternatif pendukung proses pembelajaran adalah dengan menggunakan media model Pythagoras yang dilandasi oleh pemikiran bahwa siswa lebih mudah menemukan dan memahami suatu konsep. Menurut Sugiyono (2011) media merupakan suatu benda konkret yang dirancang untuk membantu menemukan konsep dan prinsip dalam matematika. Pembelajaran dengan menggunakan media dapat memotivasi peserta didik untuk mengkaitkan materi pelajaran dengan kehidupan sehari-hari. Siswa aktif menemukan solusi masalah yang diberikan guru melalui bimbingan guru dan berusaha mencapai tujuan yang diharapkan, sehingga hasil yang diperoleh dapat maksimal.

Setelah menelaah proses pembelajaran yang sudah berlangsung dan sudah dilaksanakan dan diuraikan di atas maka permasalahan terletak pada guru sebagai penyaji materi. Oleh karena itu dilaksanakan penelitian dengan menggunakan model pythagoras dalam pembelajaran matematika. Diharapkan dengan menggunakan model pythagoras dapat meningkatkan minat belajar peserta didik sehingga hasil belajar dapat mencapai KKM. Rumusan masalah penelitian adalah: Apakah pembelajaran dengan menggunakan model pythagoras dapat meningkatkan hasil belajar matematika peserta didik?

\section{METODE PENELITIAN}

Penelitian ini termasuk penelitian tindakan kelas yaitu penelitian oleh guru yang dilakukan secara kolaboratif untuk memperbaiki proses pembelajaran yang terjadi di dalam kelas sehingga tujuan pembelajaran dapat tercapai. Menurut Arikunto (2010) penelitian tindakan kelas adalah penelitian yang dilakukan oleh guru di kelas sendiri dengan tahap; (1) perencanaan (2) tindakan, (3) pengamatan, (4) refleksi. Menurut Arikunto (2010) penelitian tindakan kelas adalah suatu penelitian yang dilakukan berdasarkan adanya permasalahan nyata yang muncul di kelas, selanjutnya berdasarkan permasalan tersebut guru mencari alternatif cara-cara untuk mengatasinya dan menindaklajuti dengan tindakan nyata yang terencana dan dapat diukur tingkat keberhasilannya.

Subjek penelitian adalah peserta didik kelas VIII.1 SMPN 4 Baso sebanyak 20 orang pada Semester II Tahun Pelajaran 2015/2016. Instrumen penelitian adalah lembar observasi, tes, dan catatan lapangan. Analisis data dilakukan secara deskriptif kualitatif yang meliputi reduksi data, penyajian data, dan penarikan kesimpulan yang diungkapkan oleh Miles dan Huberman (Moleong, 2006). Analisis kuantitatif menggunakan teknik persentase untu mengetahui keberhasilan tindakan. Kriteria keberhasilan adalah minimum $85 \%$ peserta didik tuntas dalam belajar matematika.

\section{HASIL PENEITIAN DAN PEMBAHASAN}

\section{Hasil Penelitian}

\section{Deskripsi Hasil Belajar Sebelum Pembelajaran Siklus I}

Dari hasil ulangan harian sebelum kegiatan perbaikan pembelajaran dapat diketahui hasilnya sebagai berikut, dari 20 peserta didik yang mengikuti pembelajaran matematika dapat diketahui nilai tertinggi peserta didik adalah 80 dan terendah adalah 50, dengan rata-rata hasil ulangan harian adalah 63. Distribusi frekuensi hasil belajar peserta didik sebelum siklus I dapat dilihat pada tabel 1 . 
Tabel 1. Distribusi Frekuensi Hasil Belajar Sebelum Siklus I

\begin{tabular}{|c|c|c|c|c|}
\hline No & Nilai (N) & Frekuensi (F) & NxF & Prosentase \\
\hline 1 & 50 & 4 & 200 & $20 \%$ \\
\hline 2 & 60 & 8 & 480 & $40 \%$ \\
\hline 3 & 70 & 6 & 420 & $30 \%$ \\
\hline 4 & 80 & 2 & 160 & $10 \%$ \\
\hline & Jumlah & 20 & 1260 & $100 \%$ \\
\hline & Rata-rata & & 63 & \\
\hline
\end{tabular}

Deskripsi Hasil Belajar pada Pembelajaran Siklus I

Hasil belajar peserta didik pada siklus 1 dari 20 peserta didik yang mengikuti pembelajaran matematika dapat diketahui nilai tertinggi adalah 80 dan yang terendah adaalah 50 , dengan rata-rata adalah 67. Distribusi frekuensi hasil belajar pads siklus I disajikan pada tabel 2.

Tabel 2. Distribusi Frekuensi Hasil Belajar pada Siklus I

\begin{tabular}{|c|c|c|c|c|}
\hline No & Nilai (N) & Frekuensi (F) & NxF & Prosentase \\
\hline 1 & 50 & 2 & 100 & $10 \%$ \\
\hline 2 & 60 & 6 & 360 & $30 \%$ \\
\hline 3 & 70 & 9 & 630 & $45 \%$ \\
\hline 4 & 80 & 3 & 240 & $15 \%$ \\
\hline & Jumlah & 20 & 1330 & $100 \%$ \\
\hline & Rata-rata & & 66,5 & \\
\hline
\end{tabular}

Masalah yang muncul pada pembelajaran siklus I adalah: (1) Peserta didik kurang aktif dalam mengikuti pembelajaran. (2) Kemampuan peserta didik untuk menyelesaikan tugas dan soal cerita kurang. (3) Peserta didik tidak mau bertanya karena masih sukar memahami konsep Teorema Pythagoras. (4) Kemampuan mengemukakan pendapat masih kurang baik. Rencana penyelesaian masalah dalam siklus 1 adalah: (1) Untuk mengaktifkan peserta didik dalam pembelajaran siklus 2 dengan menyusun lembar kerja yang membuat setiap anggota kelompok menjadi aktif. (2) Untuk meningkatkan kemampuan peserta didik menyelesaikan soal cerita maka pada siklus 2 dibuat variasi soal yang mudah dipahami oleh peserta didik agar peserta didik mampu memahami soal cerita dengan baik. (3) Agar peserta didik dapat memiliki kemampuan bertanya dengan baik maka pada siklus 2 guru membuat lembar kerja yang memungkinkan peserta didik lebih aktif lagi. Selain itu pada siklus 1 jumlah kelompok 5 orang sehingga ada sebagian peserta didik kurang terlibat dalam proses diskusi dalam kelompoknya, maka pada siklus 2 jumlah anggota kelompok diperkecil menjadi 4 orang dan setiap kelompok diberi kesempatan untuk menyampaikan hasil diskusinya di depan kelas. (4) Agar dapat membangkitkan kemampuan mengemukakan pendapat peserta didik maka pada siklus 2 guru memberikan tugas dan pertanyaan pada peserta didik yang kurang aktif pada siklus I.

\section{Deskripsi Hasil Belajar pada Pembelajaran Siklus II}

Setelah selesainya siklus II maka peserta didik diberi soal formatif dengan hasil sebagai berikut: Dari 20 peserta didik yang mengikuti pembelajaran matematika dapat diketahui nilai tertinggi yang diraih peserta didik adalah 90 dan yang terendah adaalah 60 , dengan rata-rata hasil tes formatif adalah 75,5. Adapun data lengkap peroleh nilai oleh peserta didik pada siklus II dapat dilihat pada tabel 3 . 
Tabel 3 Rekapitulasi Hasil Belajar pada Siklus II

\begin{tabular}{|c|c|c|c|c|}
\hline No & Nilai (N) & Frekuensi (F) & NxF & Prosentase \\
\hline 1 & 50 & 0 & 0 & $5 \%$ \\
\hline 2 & 60 & 1 & 60 & $40 \%$ \\
\hline 3 & 70 & 10 & 700 & $45 \%$ \\
\hline 4 & 80 & 6 & 480 & $10 \%$ \\
\hline & 90 & 3 & 270 & $100 \%$ \\
\hline & Jumlah & & 1510 & \\
\hline & Rata-rata & & 75,5 & \\
\hline
\end{tabular}

Pada pembelajaran siklus II permasalahan yang muncul tidak begitu berarti artinya hampir semua peserta didik telah mengikuti pembelajaran dengan baik perihal keaktifan dalam proses pembelajaran serta keaktifan bertanya pada guru sudah mulai tumbuh dengan baik. Perihal kemampuan peserta didik memahami materi soal cerita sudah membaik karena soal telah dibuat secara bahasa sederhana dan mengacu pada pengalaman peserta didik sehari-hari. Karena permasalahan dalam siklus II kurang begitu berarti maka tidak perlu adanya langkah-langkah penyelesaian masalah. Perbandingan hasil belajar peserta didik sebelum siklus I, siklus I dan siklus II disajikan pada tabel 4 .

Tabel 4. Perbandingan Hasil Belajar Peserta Didik Kelas VIII.1

\begin{tabular}{|c|l|l|l|l|}
\hline \multirow{2}{*}{ No. Uraian } & \multicolumn{3}{|c|}{ Frekuensi } \\
\cline { 3 - 5 } & & Sebelum siklus & \multicolumn{1}{|c|}{ Siklus I } & \multicolumn{1}{|c|}{ Siklus II } \\
\hline 1 & Nilai 50 & 4 orang & 2 orang & - \\
\hline 2 & Nilai 60 & 8 orang & 6 orang & 1 orang \\
\hline 3 & Nilai 70 & 6 orang & 9 orang & 10 orang \\
\hline 4 & Nilai 80 & 2 orang & 3 orang & 6 orang \\
\hline 5 & Nilai 90 & - & - & 3 orang \\
\hline 6 & Nilai Rata-rata & 63 & 66,5 & 75,5 \\
\hline 7 & Peserta didik tuntas & 8 orang & 12 orang & 19 orang \\
\hline 8 & Persentase peserta didik tuntas & $40 \%$ & $60 \%$ & $95 \%$ \\
\hline 9 & Peserta didik tak tuntas & 12 orang & 8 orang & 1 orang \\
\hline 10 & $\begin{array}{l}\text { Persentase peserta didik } \\
\text { tak tuntas }\end{array}$ & $60 \%$ & $40 \%$ & $5 \%$ \\
\hline
\end{tabular}

\section{Pembahasan}

Rata-rata yang diperoleh peserta didik sebelum siklus I sebesar 63. Peserta didik yang mendapatkan nilai 70 ke atas sebanyak 8 orang. Peserta didik yang mendapatkan nilai 60 sebanyak 8 orang. Peserta didik yang mendapatkan nilai kurang dari 60 sebanyak 4 orang. Peserta didik yang telah dinyatakan memiliki ketuntasan belajar (dengan nilai 70 ke atas) sebanyak 8 orang dari jumlah 20 peserta didik atau $40 \%$. Rata-rata yang diperoleh peserta didik pada siklus I sebesar 66,5. Peserta didik yang mendapatkan nilai $70 \mathrm{ke}$ atas sebanyak 12 orang. Peserta didik yang mendapatkan nilai 60 sebanyak 6 orang. Peserta didik yang mendapatkan nilai kurang dari 60 sebanyak 2 orang. Peserta didik yang telah dinyatakan memiliki ketuntasan belajar (dengan nilai 70 ke atas ) sebanyak 12 orang dari jumlah 20 peserta didik atau $60 \%$. Rata-rata yang diperoleh peserta didik pada siklus II sebesar 75,5. Peserta didik yang mendapatkan nilai $70 \mathrm{ke}$ atas sebanyak 19 orang. Peserta didik yang mendapatkan nilai 60 sebanyak 1 orang. Tidak ada peserta didik yang mendapatkan nilai kurang dari 60. Peserta didik yang telah dinyatakan memiliki ketuntasan belajar (dengan nilai 70 ke atas) sebanyak 19 orang dari 
jumlah 20 peserta didik atau 95\%, sedangkan peserta didik yang belum tuntas sebanyak 1 orang dari jumlah 20 peserta didik atau $5 \%$.

Setelah melaksanakan pembelajaran dengan menggunakan model Pythagoras tampak bahwa hasil klasikal dari nilai pretest sebelum pembelajaran dengan model Pythagoras jika dilihat dari nilai rata-rata kelas memang sudah kurang baik yaitu dapat dilihat bahwa rata-rata nilainya 63 dan rata-rata nilai harian setelah mendapatkan pembelajaran dengan model Pythagoras mencapai 75,5. Lagi pula jika dicermati lebih mendalam tampak bahwa ada sebanyak 19 peserta didik dari 20 peserta didik atau sebanyak $95 \%$ peserta didik pada siklus II yang mendapatkan nilai posttest lebih dari 70. Hal ini berarti bahwa dari segi ketuntasan belajar dapat dilihat bahwa dengan adanya pembelajaran dengan menggunakan model Pythagoras ternyata telah memacu peserta didik untuk lebih termotivasi belajar, sehingga dampaknya pada hasil belajar hanya 1 peserta didik atau $5 \%$ peserta didik yang tidak tuntas. Dari uraian di atas dapat disimpulkan bahwa pembelajaran dengan menggunakan model Pythagoras pada pembelajaran matematika di SMP Negeri 4 Baso dapat meningkat hasil belajar peserta didik. Hal ini sejalan dengan penelitian Hartati (2012) dan Sumiati (2009) yang menyimpulkan bahwa hasil belajar peserta didik pada mata pelajaran matematika pada pokok bahasan geometri bangun ruang balok dan kubus dengan alat peraga tiga dimensi dapat meningkatan hasil belajar.

Hamalik (dalam Arsyad, 2011) menyatakan bahwa penggunaan media pembelajaran dapat membangkitkan keinginan dan minat yang baru, membangkitkan motivasi dan rangsangan belajar, dan membawa pengaruh psikologis terhadap siswa. Penggunaan media pembelajaran pada tahap orientasi pembelajaran akan sangat membantu keefektifan proses pembelajaran dan penyampaian materi pelajaran pada saat itu. Selain membangkitkan motivasi dan minat siswa, media pembelajaran juga dapat membantu siswa meningkatkan pemahaman, menyajikan data dengan menarik dan terpercaya, memudahkan penafsiran data, dan memadatkan informasi. Usman (2005) mengemukakan bahwa belajar lebih efektif jika dibantu dengan alat peraga.

\section{KESIMPULAN DAN SARAN}

Nilai rata hasil belajar matematika peserta didik kelas VIII.1 pada siklus I sebesar 66,5 dan pada siklus II sebesar 75,5 sehingga terdapat kenaikan nilai rata-rata dari siklus I ke siklus II. Persentase ketuntasan belajar peserta didik pada siklus I menunjukkan angka sebesar 60\% (12 peserta didik tuntas dalam belajarnya dari seluruh peserta 20 peserta didik), pada siklus II sebesar 95\% (19peserta didik tuntas dalam belajarnya dari 20 peserta didik). Dengan demikian terdapat peningkatan ketuntasan belajar peserta didik dari siklus I ke siklus II. Hal ini berarti bahwa model Pythagoras dapat meningkatan hasil belajar peserta didik pada mata pelajaran matematika. Diharapkan guru dapat menggunakan model Pythagoras dan media pembelajaran lainnya sesuai dengan topik yang dibahas dalam proses pembelajaran.

\section{DAFTAR PUSTAKA}

Arikunto, Suharsimi (2010). Prosedur Penelitian:

Suatu Pendekatan Praktik. Jakarta: PT

Rineka Cipta.

Arsyad, Azhar (2011). Media Pembelajaran.

Jakarta: Rajawali Press.

Hamalik, O. (1992). Media Pendidikan. Bandung: Penerbit Alumni.

Hartati (2012). "Penggunaan Media Sederhana Sebagai Media Pembelajaran Untuk Meningkatkan Hasil Belajar Matematika" JTEQIP. Tahun III. Nomor 1.

Ibrahim dan Suparni (2012). Strategi Pembelajaran Matematika. Yogyakarta: UIN Sunan Kalijaga. 
Moleong, Lexy J. (2006). Metode Penelitian

Kualitatif. Bandung : PT. Remaja

Rosdakarya.

Ngadino (1986). Media Pendidikan. Jakarta : Bumi Aksara.

$\begin{array}{lrr}\text { Sugiyono (2011). } & \text { "Alat Peraga } & \text { dalam } \\ \text { Pembelajaran } & \text { Matematika". } & \text { Makalah } \\ \text { disampaikan pada pelatihan materi } & \text { parang, } \\ \text { matematika KKG MI Kec. Trincing, Secang, } \\ \text { Jateng. }\end{array}$

Sumiati (2009). "Penggunaan Alat Peraga Tiga Dimensi dalam Meningkatkan Hasil Belajar Matematika Pokok Bahasan Geometri Bangun Ruang (Penelitian Tidakan Kelas di kelas IV Sekolah Dasar Negeri 02 Nagrikaler Purwakarta Tahun Ajaran 2006/2007)". Jurnal Universitas Pendidikan Matematika. Vol. 4(1).

Usman, M.U. 2005. Menjadi Guru Profesional. Bandung: PT. Remaja Rosdakarya.

Winkel (2005). Psikologi Pengajaran. Yogyakarta: Media Abadi. 